Thomas D'haeninck

\title{
9 The Intellectual Mobility of Auguste Wagener (1829-1896) in a Transnational Network of Social Reform. A Cross-Border History
}

Auguste Wagener (1829-1896) was a prominent liberal politician and Professor of Philology at the State University of Ghent. He is an illustration of a first generation of mobile Belgians who attended international congresses related to social reform in general and (popular) education in particular. Wagener was a wellcultivated man and an influential person in the educational, political and cultural milieus of Ghent. As previous chapters in this volume have stated, recent research has shown that local educational and social reform practices cannot be dissociated from transnational connections and the international field of reformist knowledge that emerged during the second half of the long $19^{\text {th }}$ century. In this chapter, I will show how Wagener's intellectual mobility made local ideas and practices intertwine with an international network of social and educational reformers. I will argue that individual agency is of vital importance for the transnational exchange of educational knowledge. In doing so, I will aim to contribute to the study of popular education in particular and social reform in general, and gain a deeper understanding of the different mechanisms that were at play in the exchange of knowledge beyond the borders of the nation state.

\section{Auguste Wagener: Professor, politician and traveller}

In 1850, Wagener was appointed as Professor at the State University of Ghent having studied at the Universities of Bonn, Liège and the Sorbonne, and after making an archaeological educational tour in Asia Minor. Together with Joseph Bidez (1867-1945) and Paul Thomas (1852-1937), he established the reputation of the Ghent philological school. Like François Laurent (1810 - 1887) and Gustave Callier (1819-1863), he was the kind of socially engaged academic that left his ivory tower, advocated social change and progress, and got involved in public

Ә OpenAccess. (C) 2019 Thomas D’haeninck, published by De Gruyter. (cc) BY-NC-ND This work is licensed under the Creative Commons Attribution-NonCommercial-NoDerivatives 4.0 License. 
discussions. ${ }^{1}$ Wagener's teaching soon interlaced with his social engagements. Already by 1850 , his colleague professor Hubert Brasseur (1823-1890) had become involved in a heated dispute with the local clergy after contesting certain dogmatic theological principles in his course on morality. He even rejected the divinity of Christ. In his own lessons, Wagener advocated similar beliefs and openly supported Brasseur. As a result, he also became involved in a personal quarrel with the Bishop of Ghent, Lodewijk-Jozef Delebecque (1798-1864). ${ }^{2}$ Later, his efforts as Alderman for Education to expand the growth of municipal schools in Ghent would again encounter Catholic opposition. ${ }^{3}$

Wagener was part of an engaged urban elite: he frequented the meetings of the Société Huet, was the first president of the Société Littéraire de Gand (which became later the Cercle Artistique et Littéraire), honorary president of the Willemsgenootschap ('Willems Society'), deputy-chairman of the Société pour l'Encouragement des Beaux-arts de Gand, member of the Société pour le Progrès des Études Philologiques et Historiques, and Ghent Alderman for Education and Fine Arts (1863-1877). ${ }^{4}$ On a national level, Wagener was a member of the Académie Royale de Belgique. He was also active as a Liberal member of parliament between 1882 and $1886 .{ }^{5}$ In short, Wagener was a classic example of the cultivated social liberal. He was also a child of his time: like many other engaged citizens of the time, he was a jack-of-all-trades across many social themes, as becomes clear by his numerous commitments and memberships. ${ }^{6}$

1 See: Jan Art, “Wagener, Auguste (1829-1896),” UGentMemorie. Last modified April 21, 2015. www.ugentmemorie.be/personen/wagener-auguste-1829-1896; Paul Louis Désiré Thomas, Notice sur la vie et les travaux de Auguste Wagener, membre de l'Académie (Brussels: Hayez, 1898). 2 See: Emiel Lamberts, De Heilige Stoel en de zaak Laurent-Brasseur (1856) (S.l.: s.n., 1970). Wagener, however, never lost support of the university. See: Gustave Callier to Emile de Laveleye, 31 January 1856, MS 3640, Ghent University Library.

3 Kathleen Devolder, Gij die door 't volk gekozen zijt ... De Gentse gemeenteraad en haar leden 1830-1914 (Ghent : Maatschappij voor geschiedenis en oudheidkunde, 1994), 153-154; Wouter Dambre, August Wagener (1829-1896): een leven voor het onderwijs (Ghent: Archief R.U.G., 1987), $60-62$.

4 Hilda Proot-Cocquyt, Évolution d' un cercle d'agrément, 1879-1989: Koninklijke kunst- en letterkundige kring/Cercle royal artistique et littéraire (Ghent: CRAL, 2005); Dambre, August Wagener (1829-1896), 29; Michel Steels, Geschiedenis van het stedelijk onderwijs te Gent: 1828-1914 (Ghent: s.n., 1978), 135.

5 Thomas, Notice sur la vie et les travaux de Auguste Wagener, membre de l'Académie; Franz Cumont, “Auguste Wagener," in Liber Memorialis, Université de Gand, vol. 1 (Ghent: s.n., 1913), 148-157. For more information on social liberals, see: chapter 1/introduction to this volume. 6 Carmen Van Praet, "Liberale hommes-orchestres en de sociale kwestie in de negentiende eeuw. Tussen lokaal en internationaal” (PhD. diss., University of Ghent, 2015). 
Wagener was involved in several educational, political and cultural debates and has therefore become an object of study for historians. However, his international contacts have barely been studied and the role he played at international congresses (studied in chapter 8) have benignly been neglected. It has been pointed out that Wagener played a vital role in the Société Littéraire de Gand. He regularly invited foreign prominent figures such as Jules Simon (18141896), François-Désiré Bancel (1823-1871), Pascal Duprat (1815-1885) etc. to give presentations on cultural and artistic topics. However, the association's conferences also discussed social issues, for example how popular education could emancipate women and the working class.

Later, he was also in charge of the construction of the Ghent Institut des Sciences, a modern scientific laboratory based on the polytechnic schools in Heidelberg, Bonn and Berlin. Around 1880, several modern scientific institutes inspired by German models were constructed in Belgian university cities. They marked a change in view of education and introduced experimental methods as part of educational training. ${ }^{7}$ Wagener played a major role in the modernisation of the infrastructure of Ghent University. Not only did he plea for the political and financial support to construct the Institut des Sciences, he also made an educational tour to study the polytechnic schools of Dresden, Berlin and several other German and Swiss universities. ${ }^{8}$

The importance of Wagener's cross-border connections goes beyond these concrete examples. He engaged in an emerging transnational discursive field of social reform and contributed to the cross-border circulation of social knowledge. In this chapter, I wish to introduce the notion of 'intellectual mobility' in order to critically examine Wagener's presence at international congresses. My understanding of 'intellectual mobility' follows Stephen Greenblatt's use of “cultural mobility" and adds the notion of 'expert performances' to it. ${ }^{9}$ Thus, I see intellectual mobility as all the hidden and conspicuous human actions through which knowledge is spread. This can happen as a consequence of physical movements of people, but also through the circulation of texts, images and cultural goods. The places where knowledge and information are exchanged between mobile individuals, called "contact zones” by Greenblatt, are regarded as stages

7 Robert Halleux, Geneviève Xhayet, Pascal Pirot, Jan Vandersmissen and Rik Raedschelders, Tant qu'il y aura des chercheurs. Science et politique en Belgique de 1772 à 2015 (Liège: Luc Pire, 2015), 44-48.

8 Auguste Wagener, "Reisaantekeningen betreffende hoger onderwijs in Duitsland”, Ghent University Library.

9 Stephen Greenblatt, “Cultural mobility: An Introduction,” in Cultural Mobility: A Manifesto, ed. Stephen Greenblatt (Cambridge: Cambridge University Press, 2010), 1-23. 
where expert performances take place. 'Expert performances', in their turn, are a wide set of practices that aim to influence and convince fellow experts, the general public and policy makers. ${ }^{10}$ Hence, in order to truly understand these expert performances, we need to look further than what happened at these congresses and include other forms of intellectual mobility than merely the physical movement of a person in the context of these events. I will analyse how a specific rhetoric was used, how authority was claimed and, above all, how discursive fields became intertwined. In doing so, I will hope to contribute to our critical understanding of how ideas circulate in a transnational network.

\section{The social question at international congresses}

In the second half of the $19^{\text {th }}$ century, the field of social reform in general and education in particular were invigorated by a wide range of cross-border intellectual dynamics. As stated in the previous chapter, educational internationalism cannot be dissociated from the philanthropic and reformist networks that were upcoming at the time. Wagener frequented several international congresses in the 1850s and 1860s and, like several other Belgians, was part of the 'congresses elite', which can be seen as a transnational community of social experts. ${ }^{11}$ The series of meetings organised by the Association Internationale pour le Progrès des Sciences Sociales (AIPS) in the 1860s played a major role in the transnational circulation of knowledge related to education. ${ }^{12}$ Historians have argued that these four congresses were a catalyst for the dissemination of educational models such as the Maatschappij tot Nut van't Algemeen ('Society for Public Welfare'). ${ }^{13}$ At the four meetings held in Brussels, Ghent, Amsterdam and Bern, representatives of several locally embedded educational leagues and associations (among others Jean Macé (1815-1894), Luigi Luzatti (1841-1927) and Charles Buls (1837-1914)) met and built a transnational web of relations and ideas. Al-

10 Lutz Raphael, "Die Verwissenschaftlichung des Sozialen als methodische und konzeptionelle Herausforderung für eine Sozialgeschichte des 20. Jahrhunderts," Geschichte und Gesellschaft 22, no. 2 (1996): 165-193; Robert E. Kohler and Kathryn M. Olesko, "Introduction: Clio meets Science,” Osiris 27, no. 1 (2012): 1-16.

11 Nico Randeraad and Chris Leonards, "Transnational Experts in Social Reform, 1840-1880," International Review of Social History 55, no. 2 (2010): 215-239.

12 For the role of AIPS in the transnational circulation of knowledge, see also: chapters 1, 6, 7 and 8 of this volume.

13 Carmen Van Praet and Christophe Verbruggen, “'Soldiers for a Joint Cause’ A Relational Perspective on Local and International Educational Leagues and Associations in the 1860s," BMGN - Low Countries Historical Review 130, no. 1 (2015): 4-24. 


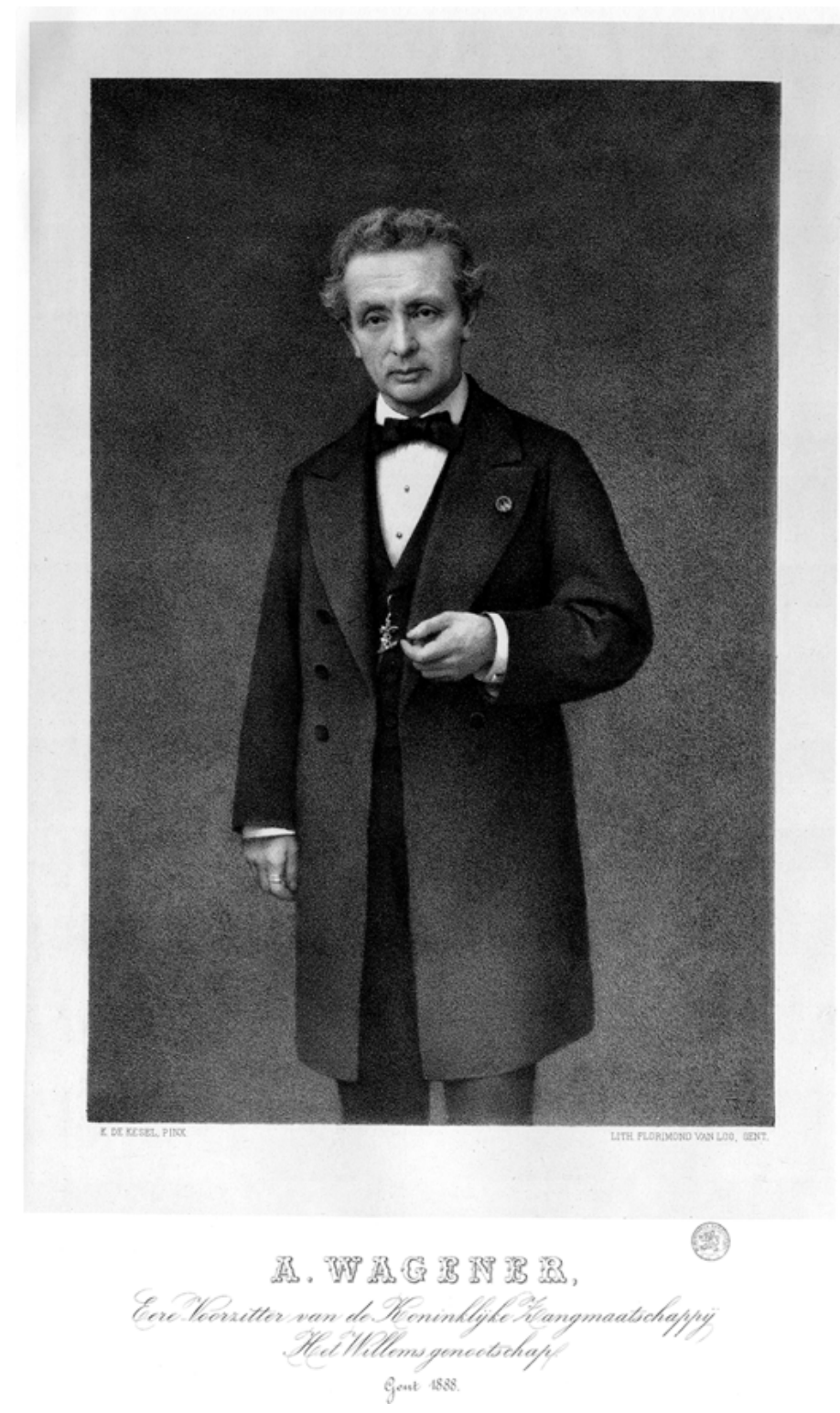

Figure 9.1: Portrait of Auguste Wagener (1829-1896), Florimond Van Loo and Karel de Kessel (1888), (Ghent University Library). This image is licensed under a Creative Commons license: https://creativecommons.org/licenses/by-sa/4.0/ 
though men mostly took the leading role during the debates, the AIPS also provided a platform for female educationalists, such as Elise Van Calcar (18221904) and Baroness Bertha von Marenholtz-Bülow (1810 - 1893). It also distributed the works of Isabelle Gatti de Gamond (1839-1905). Even though the education of disabled people was barely discussed, a few pioneers for the education of the blind and deaf, such as Charles Carton (1802-1863) and Ramon de la Sagra (1798-1871), also attended these congresses. This engendered personal contacts that led to the circulation of specialist literature.

Wagener actively participated in the third section (art and literature) of the second meeting of the AIPS held in Ghent in 1863. This section was strongly philosophical and therefore deviated from the other congresses of the 1850s and 1860s, as well as from most of the other sections of the AIPS meetings. Rapporteur Paul Voituron (1824-1891), a lawyer from Ghent and a key figure of the Liberal Party, announced at the start of the event that the debates would take a different turn: "We understand more and more that practical problems can only be solved in the light of general principles that are studied by philosophy" ${ }^{14}$

This contrasted sharply with the earlier congresses, where the attendants reported on the current situation of legal, educational, or social issues, or discussed the pros and cons of certain reform models and practices. In Brussels, for example, the section started the debates with many papers on didactical methods for the education of the arts. ${ }^{15}$ In Ghent, the Frenchman Louis Danel (1789-1875) was the only person to present a concrete didactical method (on popular music education), simply because it was agreed at the Brussels meeting that he should do so at the next meeting of the AIPS (i.e. the Ghent meeting).

As a Professor of Greek and Latin and Alderman for Education, one would expect Wagener to actively participate in the second section on education and instruction, where questions were raised on the role of the classical languages in modern education and the role of the state in stimulating (popular) educational practices. However, he was only involved in the third section on art and literature. Clearly, he did not think it necessary to participate in debates where practices and concrete models were compared. After all, these discussions often went astray, since speakers tended to dispute each other's thesis based on factual or contextual constraints.

Wagener joined the debate on the influence of the artistic genius on society. The question was raised on 15 September, but soon ran into a dead end as a re-

14 Annales de l'Association internationale pour le progrès des sciences sociales: Congrès de Gand (Brussels: A. Lacroix, 1864), 39.

15 Annales de l'association internationale pour le progrès des sciences sociales: Congrès de Bruxelles (Brussels: A. Lacroix, 1863), 368-376. 
sult of ideological differences. On the one hand, Charles Potvin (1818-1902) argued that societies evolved according to a cyclical pattern. He strongly believed that contemporary society went through a process of degeneration and that a new cycle, based on universal moral values, was imminent. As such, artists could guide society through this process by creating artworks of great moral value. On the other hand, Clémence Royer (1830-1902) strongly expressed her beliefs rooted in social Darwinism: man in general and artists in particular were determined by their environment and hence any notion of universalism or transcending morality should be rejected. ${ }^{16}$

On 16 September, Wagener opened the discussion. First, he apologised for his absence on the previous day during Royer's speech. Wagener stated that he wanted to go beyond the discord that had brought the debate to a standstill. In order to do so, he argued that the solution for the question can be found in Immanuel Kant's theorem of the division between an objective and subjective morality, a morality of the individual (the subject) based on his intuition and reason, which he uses to understand universal morality (the object). ${ }^{17}$ Wagener combined this argument with the theory of "Du beau, du vrai et du bien" expressed by the French theorist Victor Cousin (1792-1867). ${ }^{18}$ Cousin's work stated that art should not only be esthetical (beau) or show the artists' skill and knowledge of how to depict reality truthfully (vrai), but it should also be useful and strengthen public morality (bien). Therefore, Wagener argued, if the artist understands objective morality he could have a positive influence on society through his work. Others who also referred to Kant and Cousin strongly supported Wagener's long intervention in the debate. ${ }^{19}$

16 Annales de l'Association internationale pour le progrès des sciences sociales: Congrès de Gand, 402-406. For more on Charles Potvin, see: Christoph De Spiegeleer, Een blauwe progressist: Charles Potvin (1818-1902) en het liberaal-sociale denken van zijn generatie (Brussels: ASP, 2011). For more on Clémence Royer, see: Michael A Osborne, “Almost a Man of Genius: Clémence Royer, Feminism, and Nineteenth-Century Science," Journal of the History of the Behavioral Sciences 34, no. 4 (1998): 434-436. For Royer's translation of Darwin's On the Origin of Species, see: Michel Prum, “Charles Darwin's First French Translation," in The Literary and Cultural Reception of Charles Darwin in Europe, vol. IV, eds. Thomas F. Glick and Elinor Shaffer (London: Bloomsbury, 2014), 391-400.

17 Annales de l'Association internationale pour le progrès des sciences sociales: Congrès de Gand, 43-44. See also: Immanuel Kant, Critique of Judgment, trans. Werner S. Pluhar (Indianapolis/Cambridge: Hackett Publishing, 1987); Henry Allison, Kant's Theory of Taste: A Reading of the Critique of Aesthetic Judgment (Cambridge: Cambridge University Press, 2001).

18 Victor Cousin, Du vrai, du beau et du bien, 13me édition (Paris: Didier et Cie, 1867).

19 Walter Simon, “The 'Two Cultures' in Nineteenth-Century France: Victor Cousin and Auguste Comte," Journal of the History of Ideas 26, no. 1 (1965): 45-58. 
Wagener reinforced his words by saying: "allow me to point out to the assembly that, after having been Professor in Moral Philosophy at the University of Ghent for four years, I can affirm, without presumptuousness, that I am not without knowledge on this subject". ${ }^{20}$ This was more a way of emphasising his authority than of introducing himself to the attendees of the congress. ${ }^{21}$ The majority of the latter were Belgian intellectuals who already knew Wagener. Furthermore, Wagener had also come to know several of the foreigners visiting the congress during his study travels or via correspondence. Therefore, this introduction can be seen as a stylisation of his 'expert-persona'. Although Clémence Royer almost immediately, and cynically, countered his words ("monsieur le professeur de philosophie morale partout" ${ }^{22}$ ) and rejected his arguments, especially his plea for the universal, Wagener's discourse convinced the majority of the other speakers. The Frenchmen Alexander Weil (1811-1899) and Pascal Duprat endorsed his argument and Odysse Barot (1830-1907) concluded that "Ms. Royer made a bold statement yesterday. She has abandoned it today".23

In order to make his point come across, Wagener wanted to avoid any association between universal morality and the appreciation of (religious) dogmatism, which Royer, but also Count Louis-Alexandre Foucher de Careil (18261891) and Odysse Barot, seemed to criticise him for. Hence, he highlighted his earlier dispute with Bishop Delebecque: "the bishop honoured me with a pastoral letter exclusively focused on me". ${ }^{24}$

Wagener was strongly convinced of this idea of two-part morality and he believed that subjective morality could be stimulated via education and impulses that stimulated people's capability to reason. Therefore, he argued in favour of all kinds of encouragement and pleaded for several measures that the state needed to take in order to stimulate public art and popular education. Although Wagener elaborated on his earlier argument, which most of the other attendants had agreed on, he hardly received any support at all for his belief in grant-in-aid

20 Annales de l'Association internationale pour le progrès des sciences sociales: Congrès de Gand, 408.

21 See: Stephen Hilgartner, Science on Stage: Expert Advice as Public Drama (Stanford: Stanford University Press, 2000); Mineke Bosch, "Persona and the Performance of Identity. Parallel Developments in the Biographical Historiography of Science and Gender, and the Related Uses of Self Narrative," L'Homme 24, no. 2 (2013): 11-22; Mineke Bosch, "Scholarly Personae and Twentieth-Century Historians: Explorations of a Concept,” BMGN-Low Countries Historical Review 131, no. 4 (2016): 33-54.

22 Annales de l'Association internationale pour le progrès des sciences sociales: Congrès de Gand, 409.

23 Ibid, 444.

24 Ibid, 441. 
for public art, nor for his proposal to reward eminent artists via public funds and art competitions. In his plea, he reflected on the influence of the Belgian state and local governments on the intellectualisation and civilisation of its citizens. Apart from the (hesitant) support of Pascal Duprat and the Belgian author Hendrik Conscience (1812-1883), Wagener was completely isolated. Conscience admitted that, given his particular situation - he had been on the payroll of the Belgian state many times - he felt obliged to support Wagener's statements on the benefits of the influence of the Belgian government.

The majority of attendants strongly believed in a free and liberal society. Other speakers countered Wagener and pinpointed the baleful influence tyrannies had exerted in the past by conducting and censoring artists and writers, and praised havens for creative geniuses and free spirits, such as the Greek poleis or Florence during the late renaissance. ${ }^{25}$ Wagener tried to contest some of their historical facts and made counterarguments using Belgian examples, but without any success. Moreover, one of Wagener's critics, a German living in Brussels, explicitly contradicted him on the situation in Belgium, accused him of being blinded by patriotism and even scornfully laughed at him. ${ }^{26}$

At this pan-European forum for engaged intellectuals, we can see three rhetorical strategies come together in Wagener's discourse. First, he refers to his local and professional roots in order to style his expert-persona and build his image as a dyed-in-the-wool liberal and anti-dogmatist. His expert performance convinced the majority of the attendants and his argumentation on the influence of the artistic genius was included in the congress report. However, in his plea for state support for artists he referred to typical Belgian examples, which did not lend credibility to his thesis. Second, Wagener did not get involved in the debates on the local or national implementation of certain educational practices or on the practical difficulties or political opposition one could encounter when trying to advocate social or political reform. Moreover, Wagener was most convincing when he avoided references to concrete local practices, which, for an international audience, were rather vague anyway. Other speakers who did the same thing (refer to concrete but unfamiliar examples), shared the same fate. In the third section, for example, some speakers compared certain Belgian writers to the French decadents and were heavily criticised on an array of very specific facts. As a result, many discussions got bogged down. Third, Wagener supported his arguments with ideas and theories most of the attendants were quite

25 Ibid, 451-453.

26 Ibid, 461-463. 
familiar with. He referred to both the French (Cousin) and the German (Kant) philosophical tradition.

\section{Wagener in the city council of Ghent}

The idea that the individual, and by extension society as whole, could be intellectualised via certain stimuli and incentives, was a central part of Wagener's thoughts and actions in Ghent too. Social progress was more than a material struggle. It was also a moral question, in which education had to play its part. ${ }^{27}$ Hence, Wagener professionalised the educational system and established several innovative educational practices. If we compare the situation in Ghent before and after Wagener's mandate as Alderman for Education, we can see that the numbers of students, educators and institutions almost doubled. ${ }^{28}$ His merits, however, lay beyond a mere quantitative expansion. Wagener was also keen to innovate educational institutions and professionalise teachers' training. As inspector-administrator of the State University of Ghent (1878-1895), he introduced a Flemish department to educate future teachers who had to give courses in Dutch. ${ }^{29}$ If we look at his time as administrator of the university, there are numerous instances of the influence of his foreign contacts and his study visits. ${ }^{30}$

It would be untrue to say that Wagener's policy as Alderman was strongly inspired by international ideas, but, from time to time, he did rely on his intellectual mobility (i.e. the meetings of the AIPS) in his discourse as Alderman. Thus, the discursive fields of the city council and a transnational network of social reformers became intertwined.

The implementation of Froebel's model of the "Kindergarten", a creative learning environment for toddlers and pre-schoolers, which became the oldest European educational movement, is a clear illustration of how ideas spread across borders and were purposefully used in local debates. The first pilot project in Ghent was launched in 1860, a few years before Wagener was elected and became Alderman for Education. After Brussels, Ghent was the first city in Belgium where a kindergarten modelled after Friedrich Froebel (1782-1852) was estab-

27 Auguste Wagener, Rapport de la commission de l'instruction publique et des beaux-arts sur l'augmentation de traitement du personnel enseignant des écoles communales (s.l.: s.n., 1866). 28 Steels, Geschiedenis van het stedelijk onderwijs te Gent: 1828-1914, 204-205.

29 Ibid, 204.

30 Auguste Wagener, "Reisaantekeningen betreffende hoger onderwijs in Duitsland", Ghent University Library; Dambre, August Wagener (1829-1896), 30 -33. 
lished. ${ }^{31}$ Wagener attached a lot of importance to the Froebel method for the education of kindergarten teachers. He pleaded for special training schools. ${ }^{32}$ This was long before the Royal Decree of March 1880, by which the national government organised temporary training courses in the method and before the journal Le Journal-Froebel Belge was founded in $1884 .^{33}$

Belgium and the Netherlands were among the first countries in which the Froebel model was introduced, only a few years after Germany and the United Kingdom. ${ }^{34}$ Froebel's ideas were mainly spread via the travels and publications of Baroness Bertha von Marenholtz-Bülow. ${ }^{35}$ This Prussian upper-class lady established a reputation in the German states as a good friend of Adolph Diesterweg (1790 -1866), a leading progressive-liberal from Berlin, who campaigned for the secularisation of education. She met Froebel in 1849.

In her opinion, the kindergarten was the start for every educational and social change. It was the place par excellence were a kind nature could be nurtured and where children could be made into responsible and civilised future citizens. ${ }^{36}$ Her talks at the second Congrès International de Bienfaisance (Frankfurt, 1857) and the first meeting of the AIPS (Brussels 1862) were of major importance,

31 The first Kindergarten was in Ixelles (1857), the second in Brussels (1858) and the third in StJosse-ten-Node (1859). See: Carlos Martens, "Pedagogen uit Thüringen en hun invloed op het onderwijs in België,” 2006, 14, https://www.uni-jena.de/unijenamedia/Pedagogen_uit_Thuer ingen__tekst.pdf.

32 Steels, Geschiedenis van het stedelijk onderwijs te Gent: 1828-1914, 177.

33 Steels, Geschiedenis van het stedelijk onderwijs te Gent: 1828-1914, 177; Carlos Martens, "Pedagogen uit Thüringen en hun invloed op het onderwijs in België," 15; Muriel Leblon, "La formation du personnel enseignant des écoles gardiennes en Belgique: le point du vue législateur (1880 - 1914) et la création de la première école normale Fröbel (1910),” Belgisch Tijdschrift voor Nieuwste Geschiedenis 22, no. 3-4 (1991): 657-690.

34 Maurits De Vroede, An Bosmans-Hermans, and Henri Cammaer, Bijdragen tot de geschiedenis van het pedagogisch leven in Belgie in de 19de en 20ste eeuw (Leuven: KUL, 1973); Helen May, Kristen Nawrotzki and Larry Prochner, Kindergarten Narratives on Froebelian Education: Transnational Investigations (London: Bloomsbury Publishing, 2016); Evelyn Mary Lawrence, Friedrich Froebel and English Education (London: University of London Press, 1952); Johannes FroebelParker, The Life of Frederick Froebel: Founder of Kindergarten by Denton Jacques Snider (1900) (S.l.: Author House, 2013); Jean-Noël Luc, "La diffusion des modèles de préscolarisation: en Europe dans la première moitié du XIXe siècle,” Histoire de l'éducation 82 (1999): 189-206.

35 Froebel Parker, The Life of Frederick Froebel, XV.

36 Edouard Ducpétiaux, Congrès international de bienfaisance de Bruxelles: Annexes (Brussels: Decq, 1857), 295-330. 
since several of the key figures in the later spread of the Froebel model were present at these congresses. ${ }^{37}$

The international congresses on social and educational reform would continue to play a vital role in the spreading of the Froebel kindergarten. In the 1880s, there were sessions and papers organised at the international conferences on education in Brussels (1880) and London (1884) on "la méthode Froebel". At the end of the century, when more models for pre-school kindergartens found their way, Froebel was regularly mentioned in discussions on the education of toddlers at educational congresses, as well as on international congresses on the protection of the child. ${ }^{38}$

In 1866, Wagener presented his education policy and the planned budget to the Ghent city council. He announced two innovations: he proposed for popularising the idea of school saving and he wanted to further establish Froebel's kindergartens in Ghent. In order to do the latter, an initial introduction of the Froebel model had to be incorporated into the teacher training colleges in the city districts of St-Pierre-Alost and St-Pierre-Ayeghem. Although Wagener claimed that this innovative model had been successful so far, he neglected to refer to fruitful pioneering schools or give any other kind of specific information. As a conclusion to his address, he wanted to remind the city council of the following: "A few years ago, the Assocation pour le Progrès des Sciences Sociales held its second session in Ghent. The first magistrate of the city made an allusion to the children of our schools, who marched past the members attending the conference. 'We are going to show you', he said with reason, 'the most valuable possession of the city of Ghent, of which the city is most proud"'.39

The members of the city council could relate to Wagener's references, since they had been present at the congress. Wagener thus legitimised his policy by associating it with successful foreign examples and international prestige. He continued his argument by claiming that these innovations were in line with the ideas of his predecessor Gustave Callier and that they needed to seize the op-

37 May, Nawrotzki and Prochner, Kindergarten Narratives on Froebelian Education: Transnational Investigations; Nelleke Bakker, "Cylinders and Séances: Elise van Calcar and the Spirit of Froebel," History of Education 42, no. 2 (2013): 147-165.

38 This was part of what Marie-Sylvie Dupont-Bouchat has described as the emergence from the 1870s onwards of the idea of child protection as a major cause on an international level. See: Marie-Sylvie Dupont-Bouchat, “Du tourisme pénitentiaire à 'l'internationale des philanthropes'. La création d'un réseau pour la protection de l'enfance à travers les congrès internationaux (1840 -1914)," Paedagogica historica 38, no. 2-3 (2002): 53-563. See also: chapter 2 of this volume.

39 Ville de Gand. Bulletin communal (Ghent: Annoot-Braeckman, 1866), 66. 
portunity presented by the first visit of King Leopold II (1835-1909) and Queen Marie-Henriette (1836-1902) to Ghent to show their pioneering work in the field of education. ${ }^{40}$ The report was adopted.

Wagener showed a similar rhetoric, a few years later, in the city council on the question of whether the establishment of a "Théâtre National" in Ghent would improve the quality of the Flemish theatre. This matter was previously discussed at the Ghent section of the Nederlandsch Tooneelverbond ('Dutch Theatre Association'). The Nederlandsch Tooneelverbond was both a training school for actors and a national Dutch theatre company where the best actors and directors were financially supported to work on morally approved performances. ${ }^{41}$ On the Nederlandsche Taal- en Letterkundige Congressen ('Dutch Linguistic and Literary Congresses'), this covenant was promoted as an international vehicle for the entire Dutch-speaking area, that would bring the Dutch language and culture to new heights. ${ }^{42}$ During the first years, Antwerp and Ghent were the only Flemish cities willing to contribute to this experiment. The liberal flamingant Emmanuel Van Driessche (1824-1897) pointed this out at the twelfth Nederlandsche Taal- en Letterkundige Congres in 1872 in Middelburg. The congress showed its support for the Nederlandsch Toneelverbond in Belgium. ${ }^{43}$

Wagener was in favour of the establishment of a Théâtre National and regarded it as a way to improve the artistic quality of the local theatre companies, as well as a means to strengthen Dutch as a cultural language and educate and moralise the working class. He was certainly not the only member of the city council with this opinion. Julius Vuylsteke (1836-1903), for example, who cofounded the Nederlandsch Tooneelverbond and the Ghent section, also expressed

40 Ibid, 56-66.

41 Ton Van Kalmthout, Muzentempels: multidisciplinaire kunstkringen in Nederland tussen 1880 en 1914 (Hilversum: Uitgeverij Verloren, 1998); Hans Van Maanen, Het Nederlandse toneelbestel van 1945 tot 1995 (Amsterdam: Amsterdam University Press, 1997); Carlos Tindermans, "Het Nederlandsch Tooneelverbond. Een mislukt experiment in Nederlandse toneelsamenwerking," Ons erfdeel, no. 5 (1972): 41-58; Frank Peeters, “ “Te zijn of niet te zijn': Toneelletterkunde en theaterpraktijk als manifestatie van burgerlijke beschaving," in Hoofdstukken uit de geschiedenis van de Vlaamse letterkunde in de negentiende eeuw. Deel 3 (Ghent: Koninklijke Academie voor Nederlandse Taal- en Letterkunde, 2003); Jeroen Jansen and Nicolaas Theodorus Johannes Laan, Van hof tot overheid: geschiedenis van literaire instituties in Nederland en Vlaanderen (Hilversum: Uitgeverij Verloren, 2015).

42 Programma van het elfde Nederlandsch taal- en letterkundig congres (Leuven: Vanlinthout, 1869), 124.

43 Handelingen van het XIIe Nederlandsch taal- en letterkundig congres, gehouden te Middelburg, den 3, 4 en 5 september 1872 (Middelburg: J. C. \& W. Altorffer, 1873), 82-85. 
his belief that the theatre enlightened society and the working class. ${ }^{44}$ However, the proposition to appoint an additional artistic director for the Minard theatre, with the special assignment of promoting Dutch plays, was heavily criticised. Several members of the city council did not think highly of Dutch as a language for culture and fine arts. Liberal council member Octave Groverman (1831-1897) criticised it fiercely and illustrated the low quality of Dutch plays: "Instead of Mozart, the public has to endure 'Jaeksken met zijn fluitje', accompanied by vulgar jokes and nonsense that rather belong in the barracks of St. Pierre than in a subsidised theatre". ${ }^{45}$ Groverman pointed out that the working class was hardly ever present in the theatres of Ghent and he was concerned that subsidised companies would hold a monopoly without the obligation to meet certain artistic standards. ${ }^{46}$

Those in favour of subsidising the Flemish theatre had to counter both the criticism of the quality of the Dutch plays performed in Ghent and that of the principle itself of subsidising theatre companies. Julius Vuylsteke claimed that amateur theatre groups would not disappear when a theatre company received subsidies, as amateur groups still thrived in the Netherlands despite the existence of publically supported companies. ${ }^{47}$ Wagener referred to the French politician Jules Simon, one of the key figures of the AIPS and also a frequenter of the meetings of the Société Littéraire de Gand: “Gentlemen, let me make a comparison: some time ago, M. Jules Simon once said in Ghent, and this word has frequently been repeated since, that the state has the duty to prepare its own dismissal. Well likewise, amateur theatre companies also have to prepare their own dismissal". ${ }^{48}$ Wagener claimed that these words were in favour of the further professionalisation of the Ghent theatre companies. Even though Groverman pointed out that Simon's words were wrongly interpreted, Wagener's discourse convinced the city council. ${ }^{49}$

In both debates, we see Wagener referring to knowledge he obtained via his intellectual mobility. First, the arguments in his discourse were partially built on ideas and practices that circulated in a transnational network he was part of. He

44 José Verschaeren, "Julius Vuylsteke (1836-1903). Klauwaard en Geus,” Wetenschappelijke Tijdingen. Tijdschrift over de geschiedenis van de Vlaamse beweging 62, no. 2 (2003): 137-49; Bart D'hondt, Van Andriesschool tot Zondernaamstraat (Ghent: Liberaal Archief/Snoeck, 2014), $72-73$.

45 Ville de Gand. Bulletin communal, 1871, 269.

46 Ville de Gand. Bulletin communal, 1871, 264-266.

47 Ibid, 289.

$48 \mathrm{Ibid}, 284$.

49 Ibid, 298. 
made these references in order to present his policy as coherent, realistic and well-considered, and he associated them with the success and prestige of foreign realisations. Second, Wagener linked his policy to people, practices and events that were well-known to his audience. Third, he positioned Ghent in an international tradition of (educational) innovation and responded to the city council's sense of honour and prestige.

\section{Conclusion}

This micro-analysis of Auguste Wagener's positioning in the selected debates has shown that his intellectual mobility lead to an intertwining of local and international discursive fields. The way Wagener relied on certain pieces of knowledge illustrates the complex process of performing expertise in a transnational network. In this process of persuasion, we see Wagener constructing his expert-persona by making associations with people, practices and events that were well known to his audience. At the meetings of the AIPS he referred to well-known German and French philosophers, while in the city council he talked about the renowned Jules Simon and a prestigious event that had recently taken place in Ghent.

The success of his words was not so much determined by their factuality, but rather by their power to persuade his audience. At the AIPS, Wagener referred to his local and professional background to claim expertise on morality and underline his non-dogmatic thinking, while in the city council he linked local practices to international prestige. These were two well-chosen references, which were in line with the prevailing views of his audience. I argue that Wagener's discourse aimed to construct his persona by its association with the familiar, the prestigious, the local and the international. Hence, whether these performances were persuasive or not was highly dependent on the specific nature of his audience. On the Congrès International de l'Enseignement, organised in Brussels almost two decades later (in 1880), Wagener participated in a debate on moral education and arguments similar to those he had successfully used in 1863 at the meetings of AIPS. However, many of the attendants were advocates of social Darwinism and Wagener's words were soon discredited and framed as out of fashion, and he himself was referred to as an old man who lived in the past. ${ }^{50}$

50 Paul Thomas, Congrès international de l'enseignement: discussions; discours (Brussels: Hayez, 1882), 301-325. 
Hence, the circulation of knowledge in a transnational network is not a oneway street or a symmetrical transfer between interrelated intellectual milieus. Rather, it highly depends on individual agency. It is a process that is strongly determined by the position of individuals in certain groups and by the persuasiveness of their expert performances. 